\title{
The importance of phytoplankton production for carbon budgets in a semiarid floodplain wetland
}

\author{
by \\ Miguel Álvarez-Cobelas ${ }^{1}$, David G. Angeler ${ }^{2}$, Carmen Rojo ${ }^{3} \&$ Santos Cirujano $^{4}$ \\ ${ }^{1}$ National Museum of Natural History, CSIC, Serrano 115 dpdo., E-28006 Madrid, Spain. malvarez@mncn.csic.es \\ ${ }^{2}$ Swedish University of Agricultural Sciences, Department of Aquatic Sciences and Assessment, PO Box 7050, SE-75007 Uppsala, Sweden \\ ${ }^{3}$ Cavanilles Institute of Biodiversity and Evolutionary Biology, University of Valencia, P.O. Box 2085, E-46071 Valencia, Spain \\ ${ }^{4}$ Royal Botanical Garden, CSIC, Plaza de Murillo 2, E-28014 Madrid, Spain
}

\begin{abstract}
Álvarez-Cobelas, M., G. Angeler, D., Rojo, C. \& Cirujano, S. 2011. The importance of phytoplankton production for carbon budgets in a semiarid floodplain wetland. Anales Jard. Bot Madrid 68(2): 253-267.

Phytoplankton production (PP) in wetlands is not measured as often as that of macrophytes. A three year-study during a period of sustained high flooding was undertaken in a central Spanish floodplain wetland (Las Tablas de Daimiel National Park) to determine net PP, its spatial heterogeneity and controlling factors, and compare it with primary production in macrophyte communities. This enabled us to estimate carbon budgets for each community. All PP variables showed high spatial and temporal variability among sites, resulting in low coherence even when flooding connected all sites. Net PP corresponded to 25$36 \%$ of submerged plant production and $3-10 \%$ of helophyte production. Net PP was controlled by different size fractions of phytoplankton biomass at different wetland sites. Neither nutrients nor zooplankton affected net PP or productivity. A high spatiotemporal variability of PP in wetlands occurs arising from complex processes that affect the underwater light field. Carbon budgets of phytoplankton often exceeded those of submerged macrophytes and attained between 4 and $37 \%$ of helophyte budgets. Although usually considered to be marginal, our study shows that PP in the open water of wetlands should be taken into account for determining accurate wetland carbon budgets, mostly in periods of high flooding, which often result in changing the carbon budget of primary producers.
\end{abstract}

Keywords: chlorophyll-specific net primary production, plankton biomass, dissolved organic carbon, nutrients, zooplankton, macrophyte production.

\section{Resumen}

Álvarez-Cobelas, M., G. Angeler, D., Rojo, C. \& Cirujano, S. 2011. La importancia de la producción fitoplanctónica para los balances de carbono en un humedal semiárido de llanura de inundación. Anales Jard. Bot. Madrid 68(2): 253-267 (en inglés).

La producción de fitoplancton (PF) en los humedales no se mide tan a menudo como la de los macrófitos. En este estudio se lleva a cabo un trabajo de tres años durante un periodo de gran inundación en un humedal de llanura de inundación (Parque Nacional de Las Tablas de Daimiel) a fin de determinar la producción neta del fitoplancton, su heterogeneidad espacial y los factores que la controlan. También comparamos la PF con la producción primaria de las comunidades de macrófitos, lo cual nos permite estimar las cantidades de carbono que fija cada comunidad vegetal. Todas las variables relacionadas con la PF mostraron mucha variabilidad espacial y temporal, lo cual dio como resultado una escasa relación entre la producción de unos lugares y otros, incluso cuando la inundación los conectó a todos. La PF neta estuvo entre un 25 y un $36 \%$ de la producción de los macrófitos sumergidos y entre un 3 y un $10 \%$ de la producción de los helófitos. La PF neta estuvo controlada por algas de diferente tamaño en los distintos sitios del humedal. Ni los nutrientes ni el zooplancton afectaron a la PF neta o a su productividad. La gran variabilidad espacio-temporal de la PF en los humedales se debe a una serie de procesos complejos que afectan al ambiente luminoso subacuático. Las cantidades de carbono fijadas por el fitoplancton a menudo superan a las de los macrófitos sumergidos y pueden llegar a suponer entre un 4 y un $37 \%$ del carbono de los helófitos. Considerada normalmente como marginal, la PF en las aguas libres de los humedales debería tenerse en cuenta a la hora de determinar con precisión la cantidad de carbono de los humedales, especialmente en periodos de gran inundación que a menudo dan como resultado cambios en el balance de carbono de los productores primarios.

Palabras clave: producción primaria neta específica para la clorofila, biomasa planctónica, carbono orgánico disuelto, nutrientes, zooplancton, producción de macrófitos. 


\section{Introduction}

The measurement of phytoplankton production (PP hereafter) has a long tradition in stagnant freshwater bodies (Manning \& Juday, 1941; Talling, 1957; Rodhe, 1958). A great amount of knowledge about phytoplankton-mediated C fixation in the world's lakes and rivers has been accumulated (see reviews in Brylinsky, 1980; Westlake \& al., 1980; Álvarez-Cobelas \& Rojo, 1994). Factors controlling PP in lakes are nowadays well understood, with the influence of physical vs chemical effects playing an important role as related to trophic state characteristics (Harris, 1986; Reynolds, 2006).

However, PP in wetlands has not been studied very often, maybe because it has been assumed that phytoplankton is a minor, even negligible, component of wetland biological communities (Mitsch \& Gosselink, 2001). Few studies (Robarts \& al., 1995; Robinson \& al., 1997) have focused on shallow, clear-water wetlands, but studies in highly turbid wetlands, where high amounts of dissolved organic matter and/or particulate suspended matter can influence irradiance attenuation, and consequently PP, are almost lacking. This is unfortunate because phytoplankton can play a major role in the carbon metabolism of some wetlands (Robinson \& al., 1997; Sánchez-Carrillo \& al., 2000), thereby influencing nutrient cycling. The hydrological regime of wetlands imposes a high spatio-temporal variability on wetland communities and ecosystem processes that are by far more variable than in lakes (Mitsch \& Gosselink, 2001; Wetzel, 2001). This could translate in an even higher spatiotemporal variability of PP in fluctuating floodplains. Nonetheless, in efforts to make PP measurements cost effective, experiments in wetlands are usually limited to one sampling area (Robinson \& al., 1997), thereby missing out much environmental variability of the process.

The primary production of macrophytes has been measured very often in wetlands (Vymazal, 1995; Cronk \& Fennessy, 2001). Comparisons of primary production among different fractions of primary producers, which have been reported for lakes (Wetzel, 1964; Gessner \& al., 1996), are very uncommon for wetlands, but are certainly needed to outline carbon budgets and to emphasize (or to discard) the role that phytoplankton is playing.

Phytoplankton carbon is certainly a high share of the carbon budget in hypertrophic lakes (Âlvarez-Cobelas \& Jacobsen, 1992). Since many wetlands tend to be hypertrophic due to the continuous inputs of nutrients, phytoplankton carbon might also contribute much to the overall carbon budget in wetlands, their quantification thus becoming necessary if reliable budgets are pursued. This is also an important feature of the often held view that wetlands are often net sinks of carbon (Mitsch \& Gosselink, 2001). If this is the case, then an accurate determination of phytoplankton carbon dynamics will certainly enhance those budgets.

Therefore, this study aims at comparing primary production among plants (phytoplankton, submerged and emergent plants) to establish the importance of phytoplankton for carbon budgets. We also address the spatio-temporal variability of net PP and its controlling factors. More specifically, we will assess the role of abiotic vs biotic control of PP and how variable this control is at different, environmentally heterogeneous sites, in a floodplain wetland of Southern Europe. We will demonstrate that, despite high variability among sites and seasons, wetland net $\mathrm{PP}$ is comparable to that in lakes, and that phytoplankton productivity can contribute a substantial fraction to ecosystem productivity.

\section{Study site}

Las Tablas de Daimiel National Park (TDNP) is a 1578-ha floodplain wetland, located in central Spain $\left(39^{\circ} 08^{\prime} \mathrm{N} 3^{\circ} 43^{\prime} \mathrm{W}\right.$, Fig. 1, Table 1). It is shallower at the NE area and deeper at the SW area. Average water depth is $0.91 \mathrm{~m}$ when the whole wetland is flooded; average depth and water inputs have displayed very strong fluctuations in recent years. The height of water columns throughout the wetland is rather low in most places, thus ensuring a very fast and thorough mixing. The wetland is hypertrophic as a result of $1^{\text {st }}$ ) heavy external nutrient loading since $1980,2^{\text {nd }}$ ) a high internal loading arising from high productivity of emergent vegetation, and $3^{\text {rd }}$ ) very infrequent export of materials downstream because a terminal dam, which was built in 1986, retains water and organic matter in the wetland (Sánchez-Carrillo \& ÁlvarezCobelas, 2001; Álvarez-Cobelas \& Cirujano, 2007). Organic matter content in soils ranges from 2 to $30 \%$ and reduced, anoxic conditions prevail in the wetland soils (Álvarez-Cobelas, unpublished data). The wetland is a mixture of helophyte patches and water tables, these being colonized by charophyte meadows wherever water quality is not heavily impacted by highly polluted inputs from the catchment. Submerged vegetation is mostly comprised of Chara hispida L., which occurs mainly in central water tables. Emergent vegetation consists of cut-sedge (Cladium mariscus (L.) Pohl.) and reed (Phragmites australis (Cav.) Trin. ex Steudel), with contributions of cattail (Typha domingensis (Pers.) Steudel) in high flooding years and terrestrial plants in low flooding years. Periphyton growth, which is an important component of 


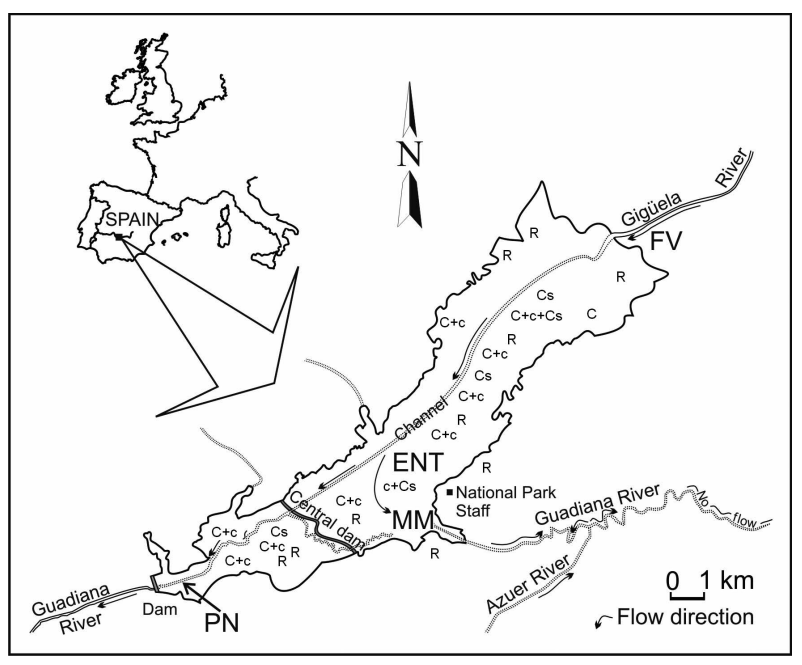

Fig. 1. Study site, showing sampling locations in the Las Tablas de Daimiel floodplain wetland (central Spain). The meteorological station is located at the facility of the National Park staff. ENT, central site; FV, inlet site; MM, central outlet; PN, terminal outlet. C, cattail (Typha domingensis) sampling site; Cs, cut-sedge (Cladium mariscus) sampling site; C, charophyte sampling site; $R$, reed (Phragmites australis) sampling site. Arrows show the main flooding courses.

the plant populations of this wetland during the long periods of low flooding, has been a minor population throughout the study period when water renewal time has been very short (Table 1; Álvarez-Cobelas, in situ personal observation).
Phytoplankton chlorophyll-a ranges from 1 to more than $200 \mu \mathrm{g} \mathrm{L}{ }^{-1}$. Plankton composition reflects the turbid, hypertrophic conditions (see nutrient concentrations in Table 1), with a high share of cyanobacteria, cryptophytes, euglenoids and diatoms (Rojo \& al., 2000); rotifers and copepods are the main planktonic secondary producers (Ortega-Mayagoitia \& al., 2000).

Further information on the wetland can be found in Álvarez-Cobelas \& Cirujano (1996, 2007), ÁlvarezCobelas \& al. (2001, 2007), Sánchez-Carrillo \& Angeler (2010) and www.humedalesibericos.com.

\section{Materials and methods}

\section{Field sampling}

This study was undertaken between 1996 and 1998, when a sustained high flooding occurred. Four sampling sites were chosen for this study (Fig. 1, Table 1). Filtro Verde $(F V)$ is the main water entrance to the wetland. It is a very shallow (usually lower than $0.5 \mathrm{~m}$ ) flow-through channel located at the NE area of the wetland, and often receives wastewater and silt from a nearby village. Molemocho (MM, the eastern water outlet site) is a deeper $(1.0-1.5 \mathrm{~m})$ pond area located in the middle of the wetland. This site was formerly a water input site of a groundwater-fed stream (Guadiana river), but aquifer overexploitation resulted in the drying-up of this site from 1986 onwards. Subsequent subterranean peat fires caused geomorphological al-

Table 1. Environmental features of the Tablas de Daimiel National Park and the studied sites. When available, ranges for the study period (1996-1998) are given. ENT, FV, MM and PN are the sites of phytoplankton primary production measurements (see Fig. 1 for location).

$\begin{array}{lc}\text { Catchment area }\left(\mathrm{km}^{2}\right): & 14,460 \\ \text { Total TDNP flooding area }(\mathrm{Ha}): & 1578 \\ \text { Maximal depth }(\mathrm{m}): & 4 \\ \text { Average depth }(\mathrm{m}): & 0.91 \\ \text { Flooding range }(\mathrm{Ha}): & 100-1815 \\ \text { Water renewal time: }(\mathrm{d}) & 34-104\end{array}$

\begin{tabular}{|c|c|c|c|c|}
\hline & ENT & FV & MM & PN \\
\hline Water level (cm) & $20-100$ & $20-234$ & $13-294$ & $20-436$ \\
\hline PAR attenuation $\left(\mathrm{m}^{-1}\right)$ & $0.1-8.2$ & $0.05-33$ & $0.1-18.3$ & $0.18-14.4$ \\
\hline Dissolved oxygen (mg/L) & $0.9-17$ & $0.8-21$ & $4-17.6$ & $5.2-16.9$ \\
\hline Water conductivity ( $\mu \mathrm{S} / \mathrm{cm})$ & $1920-11800$ & $1300-3990$ & $1480-4800$ & $2044-5310$ \\
\hline Suspended solids (mg/L) & $8.4-288$ & $2-1160$ & $6-680$ & $7-204$ \\
\hline Dissolved inorganic carbon (mg C/L) & $1.66-15$ & $0.3-43$ & $0.75-24$ & $0.12-23$ \\
\hline Total nitrogen (mg N/L) & $0.26-5.70$ & $1.09-11.84$ & $1.21-8.31$ & $1.11-8.82$ \\
\hline Total phosphorus (mg P/L) & $0.01-2.30$ & $0.067-1.84$ & $0.005-1.7$ & $0.007-1.8$ \\
\hline Chlorophyll-a ( $\mu \mathrm{g} / \mathrm{L})$ & $0.5-69$ & $3.1-206$ & $0.6-175$ & $2.8-89$ \\
\hline
\end{tabular}


terations in the form of terrain subsidence, converting this area to a surface outflow site. Dark grey peat serves there as a source of dissolved carbon and frequent winds contribute to sediment resuspension and high turbidity. Entradilla (ENT, the middle site) is $0.5-1 \mathrm{~m}$ deep, lying in the centre of the wetland and is characterized by extensive Chara hispida meadows. Finally, Puente Navarro (PN, the terminal southwestern outlet site) is a $4 \mathrm{~m}$-deep area during high floods. It lies at a distance of $14 \mathrm{~km}$ downstream from the inlet site. These four areas are only connected by surface water when the flooding area exceeds 1500 $\mathrm{Ha}$ (Álvarez-Cobelas, unpublished data). Water depth fluctuations in the wetland are highly variable below this threshold $(43 \pm 19 \mathrm{~cm})$, while they are more constant $(89 \pm 4 \mathrm{~cm})$ during high waters, when wetland connectivity is enhanced. The open water areas at these four sites were mostly surrounded by sawgrass (Cladium mariscus) and reed (Phragmites australis). Decomposition of these plants increases both dissolved and particulate nutrients in the water column and the sediments. Reed decomposition also increases the dissolved organic carbon content in the water, thereby contributing to increased light attenuation in deeper areas (Álvarez-Cobelas \& al., 2010). Temperature profiles suggested that the water column at all sites was well mixed throughout the study. All sampling sites were hydrologically connected from January to June in 1997 and 1998, i.e. during onethird of the whole study period. Sampling for this study was carried out in monthly intervals between March 1996 and December 1998.

A meteorological station $200 \mathrm{~m}$ away from the central site recorded 10-min averages of incoming solar irradiance, air temperature and wind variables. Vertical attenuation profiles of overall irradiance were determined using a LI-COR 188B meter fitted with a spherical sensor, corrected for variation in the incoming PAR irradiance at the wetland surface; a vertical coefficient of attenuation was estimated using a negative exponential law (Kirk, 1994). Since all sites showed complete mixing, water for chemical analyses was taken at an intermediate depth level using a short Niskin bottle. Conductivity, as a proxy of connectivity among wetland sites (Leibowitz \& Vining, 2003), was measured with a CRISON field probe.

\section{In situ primary production of macrophytes}

The yearly production of charophytes, reed and cattail was estimated using the peak biomass method (Cronk \& Fennessy, 2001) at ten sites which were distributed over the whole wetland (see Fig. 1). Cladium is, however, a perennial species and hence its produc- tion cannot be evaluated in the same way. This was, therefore, undertaken using the Lomnicki \& al. (1968) method, which is the sum of changes in live biomass plus the dead biomass of decaying leaves measured at the end of each sampling interval (a month). Such measurements were carried out at five sites of the wetland in each year of the study. Later an annual average production was calculated for each species. Carbon was assumed to be $40 \%$ of dry mass in emergent plants (Vymazal, 1995). In charophytes we only considered organic carbon, discarding their carbonate content and assuming that organic carbon attained $45 \%$ of their whole carbon concentration (Vymazal, 1995).

To estimate the importance of macrophyte production in the carbon budget it was necessary to calculate the yearly amount of carbon that was fixed in the whole wetland by these macrophytes. Therefore, an annual average of macrophyte cover was needed. Emergent vegetation maps of cut-sedge and reed were drawn from aerial photographs taken each year at the end of their growth period. Field surveys in 1993 by one of our team (S. Cirujano, unpublished information) allowed to ascribe photographic patterns to either cut-sedge or reed vegetation in all maps. Along with Typha increase, a special effort was made to separate Phragmites and Typha covers in aerial photographs through intensive field work. All maps were rasterized using the ARCVIEW-GIS software package (ESRI, 1996). Charophyte cover was estimated each year by thorough field surveys.

\section{Laboratory methods and calculations}

Chlorophyll-a, total phosphorus, total nitrogen and suspended solids were measured following the methods by Marker \& al. (1980) and APHA (1998). Water colour was measured following Cuthbert \& del Giorgio (1992), and converted into dissolved organic carbon (DOC) values using the formula by Rasmussen \& al. (1989).

Out of the several methods of measuring $\mathrm{PP}\left(\mathrm{C}^{14} \mathrm{ra}-\right.$ dioactivity, Winkler oxygen, fluorescence, selective electrode; Barber \& Hilting, 2002; Marra, 2002), the Clark electrode is the least used. It is however a very useful method because it enables short-term measurements, thus avoiding photoinhibition to be experienced by algal cells, as often occurs in standard incubations for either Winkler or $\mathrm{C}^{14}$ procedures (Harris \& Piccinin, 1977). A realistic approach to study PP in wetlands can be the use of Clark electrodes which allow for rapid determination of photosynthesis and parameters related to saturation irradiance, photoinhibition, and photosynthetic capacity (Harris, 1973). 
This method, which provides comparable results to radiolabelling of carbon and Winkler oxygen methods (Harris \& Piccinin, 1977), has mostly been restricted to the measurement of phytoplankton photosynthesis in the laboratory. Although used to a lesser extent in the field (Harris, 1973; Harris \& Lott, 1973; Harris \& Piccinin, 1977; Micheletti \& al., 1998), this method has been shown to provide comparable results with other more commonly used approaches (Bender \& al., 1987).

Net phytoplankton production (net PP) was measured monthly in samples collected from the four sites (Fig. 1) using a DW1 Hansatech Clark-type electrode. Measurements were taken immediately after returning to the laboratory. The time interval between sample collection and analysis of PP was usually between 2 and 12 hours. During the trip, phytoplankton samples were kept in dark and at low temperature. A Turner model 10005 fluorimeter was used to check for similar chlorophyll-a features in samples in the field and the lab after a 5 min dark preconditioning. Prior to the commencement of primary production measurements, phytoplankton samples were concentrated 20-200 fold by gentle filtration on $1.2 \mu \mathrm{m}$ Millipore filters at low vacuum pressure. This concentration process was necessary to provide a neat oxygen evolution in the electrode cuvette. Microscopic examination did not reveal any damage of phytoplankton cells, colonies or filaments after filtration. Bacterial respiration was therefore largely excluded from measurements because most bacteria living in the bacterioplankton of this wetland is usually smaller than $1 \mu \mathrm{m}$ size (Rodrigo, personal communication). Larger zooplankton detected in the filter by visual inspection was carefully removed. After filtration, samples were resuspended in $5-10 \mathrm{~mL}$ filtered water of their corresponding wetland site. Before starting oxygen recording, concentrated samples (in $3 \mathrm{~mL}$ cuvettes) were preadapted to field conditions of irradiance and temperature for $10 \mathrm{~min}$. Measurements lasted $10 \mathrm{~min}$ to diminish oxygen supersaturation, photoinhibition and phytoplankton grazing by ciliates and rotifers. To avoid oxygen supersaturation, $\mathrm{N}_{2}$ was bubbled at regular intervals. Irradiance was supplied by a Hansatech photodiode attached to the cuvette; a constant irradiance was set for the whole period of oxygen measurement, mimicking irradiance recorded in the field when retrieving phytoplankton samples. Also, the same temperature recorded in the field was held constant in the cuvette by circulating water from a refrigerated water bath. A photosynthetic quotient of 1 (Williams \& al., 1979) was assumed to be appropriate for all carbon calculations. No replicates were always measured for a given sampling in order to facilitate a rapid measurement of all samples and prevent phytoplankton damage. Selected replicate measurements, however, showed a good reproducibility of results with $3-10 \%$ errors. Productivity was considered to be the chlorophyll-scaled, net primary production at saturating irradiance.

Although we have not carried out comparisons between the Clark electrode technique and other well known methods for in situ PP determination in the years reported here, we did perform a comparison between the Winkler technique and the Clark electrode technique in summer 2009 at the same wetland sites of our 1996-1998 surveys, resulting in an explained variability of $85 \%\left(\mathrm{PP}_{\text {Winkler }}=0.54+0.96 * \mathrm{PP}_{\text {Clark }} ; \mathrm{p}<0.05\right.$, $\mathrm{N}=20$ ). The Winkler approach was undertaken in 1 hour, triplicate, light and dark incubations to minimize photoinhibition, and microtritation equipment was used (model 808 of Titrando Metrohm), which enabled high precision $\left( \pm 4 \mu \mathrm{g} \mathrm{L}^{-1}\right.$, SE of triplicate determination; Carignan \& al., 2000). The Clark procedure was done as above.

Irradiance, water depth, PAR attenuation and net PP data were used to estimate daily net PP by trapezoidal integration following the Walsby's method (1997). Since most sites were very shallow, we assumed that all water columns were thoroughly mixed, which prevented photoinhibition to occur. For the annual integration, we first calculated a multiple linear regression of measured daily PP against daily irradiance and air temperature for each sampling site and the three years of study. These equations explained $75-80 \%$ of variability in daily PP. We then used each equation to interpolate daily data for each sampling site in the days between measurements. Later, we simply estimated annual PP by summing up daily data for a given year and sampling site. Carbon budgets for each plant community and year of study were obtained by simply multiplying annual production by the cover of each community. Phytoplankton was assumed to spread throughout the flooded area.

Picoplankton was counted using fluorescence microscopy (Weisse, 1988; Ortega-Mayagoitia \& al., 2002). The remaining plankton fractions were identified and counted using an inverted microscope (Rojo \& al., 2000; Ortega-Mayagoitia \& al., 2000), attaining counting errors of $5 \%$ (Lund \& al., 1957). Biomass was calculated on a fresh weight basis, using the geometrical volumes in the case of phytoplankton, ciliates and rotifers (Rott, 1981; McCauley, 1984) and the allometric equations reported by McCauley (1984) for crustaceans. To explore the effect of size, phytoplankton biomass was also sorted by size in $10 \mu \mathrm{m}$ classes prior to 
statistical analysis. The phytoplankton size fractions chosen were $<10 \mu \mathrm{m}, 10 \mu \mathrm{m}<$ phyto size $\leqslant 20 \mu \mathrm{m}, 20$ $\mu \mathrm{m}<$ phyto size $\leqslant 30 \mu \mathrm{m}, 30 \mu \mathrm{m}<$ phyto size $\leqslant 50 \mu \mathrm{m}$ and phyto size $>50 \mu \mathrm{m}$. Ranges between 30 and $50 \mu \mathrm{m}$ were summed up because of the low fraction of phytoplankters' sizes between 40 and $50 \mu \mathrm{m}$.

Correlation analyses were carried out to determine relationships between net $\mathrm{PP}$ and productivity with electrical conductivity, water depth, water temperature, PAR attenuation, suspended solids, DOC, total nitrogen, total phosphorus, N:P ratio and ciliate, rotifer and crustacean biomass. These correlations were carried out for chlorophyll-a, total phytoplankton biomass and for the biomass in each of the individual size classes. Also, Friedman and Mann-Whitney nonparametric comparisons between years and sites were carried out for primary production variables to assess spatial and temporal heterogeneity. Temporal coherence (George \& al., 2000) of phytoplankton biomass, net PP and productivity between site pairs were assessed using Spearman correlation analyses. A high correlation between these variables at two sites would suggest a high temporal coherence between them.

\section{Results}

\section{Environmental conditions}

Hydroperiods were highly variable during the study period, in part due to extraordinarily high precipitation events in late 1996 and 1997 which completely flooded the wetland. Water depths ranged $2.01 \pm 1.08,1.82 \pm 0.81,0.47 \pm 0.22$, and $3.16 \pm 1.14$ $\mathrm{m}$ at the inlet site, the central site and the central and terminal outlets, respectively (Fig. 2a,b).

Conductivity showed seasonality for all sites with higher values during summer. The inlet station always had the lowest conductivity $\left(2.55 \pm 0.77 \mathrm{mS} \mathrm{cm}^{-1}\right)$. Highest values $\left(7.20 \pm 3.79 \mathrm{mS} \mathrm{cm}{ }^{-1}\right)$, reflecting nearly mesohaline conditions, were observed at the central site during periods when it was not connected to the other sites through surface flooding. If water conductivity was used as a surrogate of different water masses, when flooding connected all areas conductivity values were then similar across sites.

PAR attenuation was high at all sites for most of the study period (Fig. 2a,b), ranging from $2.61 \pm 1.69$ to $6.51 \pm 7.40 \mathrm{~m}^{-1}$ at the central site and the inlet site, re-
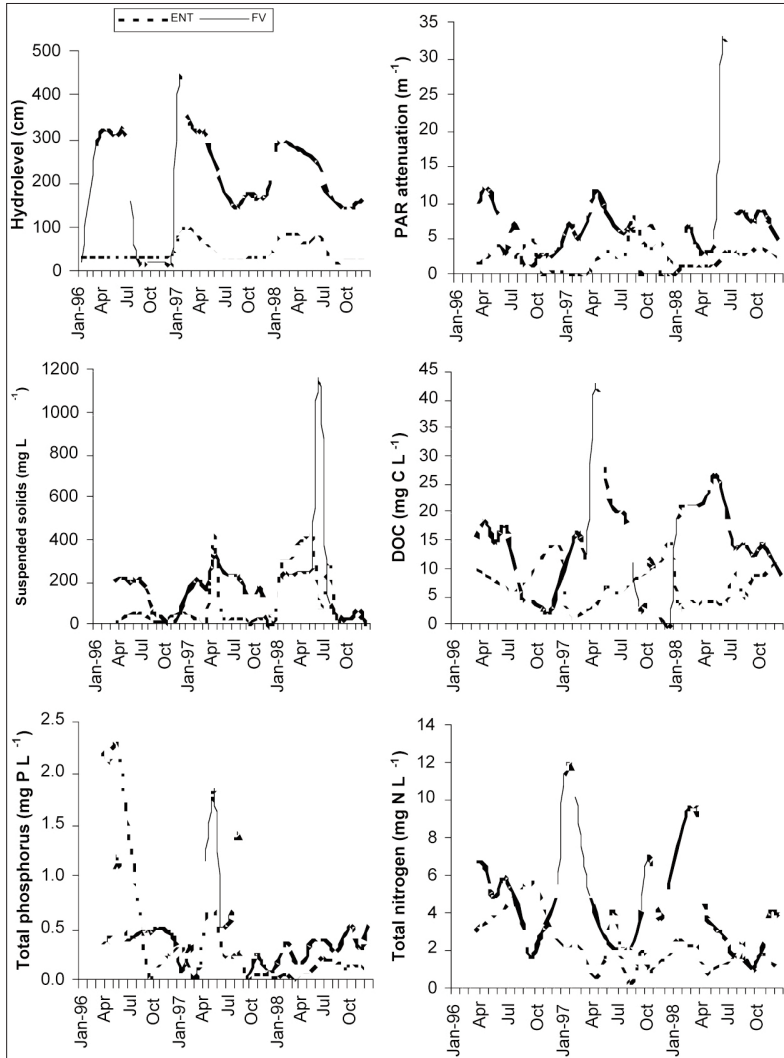

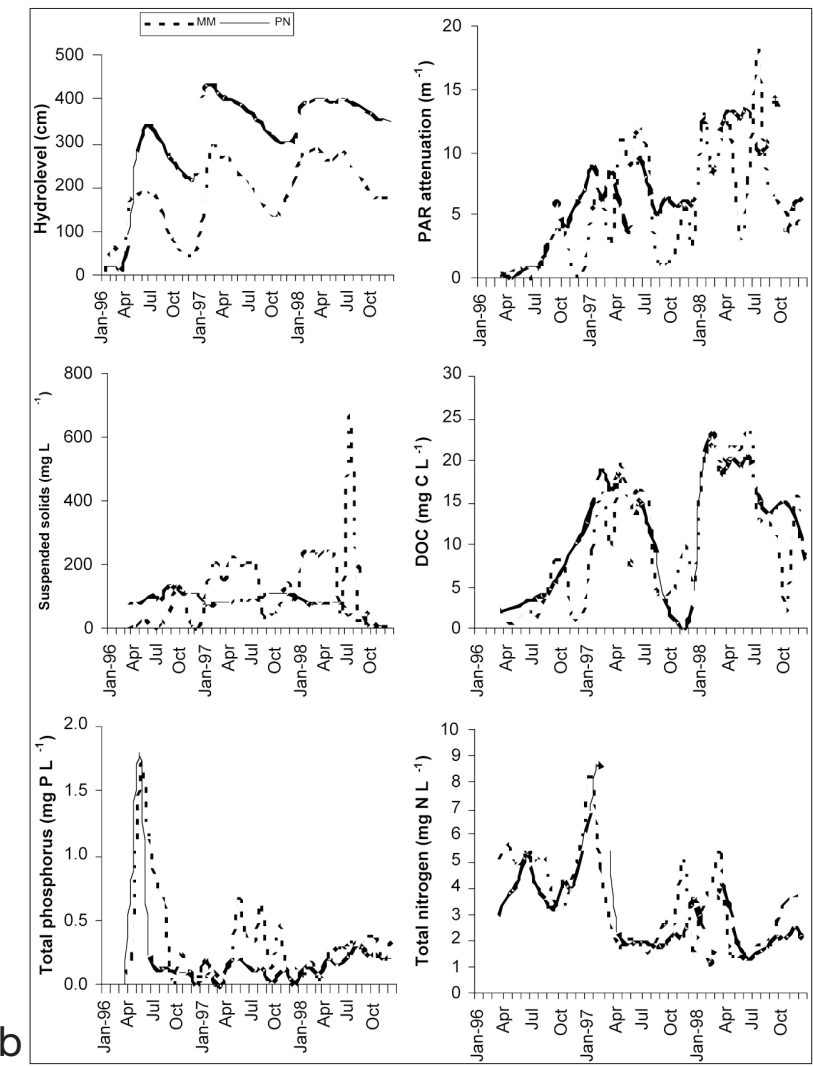

Fig. 2. Relationships of environmental factors and phytoplankton primary production recorded at four sites of Tablas de Daimiel National Park between March 1996 and December 1998. ENT, central site; FV, inlet site (Fig. 2a); MM, central outlet; PN, terminal outlet (Fig. 2b). See Fig. 1 for location. 
spectively. Also some weak seasonality appeared in the data, showing higher irradiance attenuation during summer. Amounts of suspended solids were high at the wetland inlet (FV) and in the middle outlet (MM, Fig. 2a,b). The central (ENT) and the terminal outlet (PN) showed lower suspended matter contents with peaks during summer. DOC concentrations at the inlet site were the highest, peaking in late spring (Fig. 2a,b). DOC at the other sites was also seasonal, with maxima occurring during autumn, coinciding with reed senescence and sediment resuspension promoted by the usually strong winds of autumn. DOC contents were lowest at the central site (ENT; $7.48 \pm$ $\left.3.59 \mathrm{mg} \mathrm{C} \mathrm{L}^{-1}\right)$ and highest at the inlet site (FV, $14.34 \pm$ $\left.8.80 \mathrm{mg} \mathrm{C} \mathrm{L}^{-1}\right)$. The other sites also showed relatively high values.

Similar temporal patterns were found for total nitrogen concentrations; highest values were observed at the inlet site, lowest values occurred at the central site and intermediate values were recorded at the other sites (Fig. 2a,b). Total phosphorus showed highest variability at the central site, peaking in late spring and summer. Total phosphorus concentrations ranged from $0.212 \pm 0.310 \mathrm{mg} \mathrm{P} \mathrm{L}^{-1}$ at the outlet site to 0.473 $\pm 0.385 \mathrm{mg} \mathrm{P} \mathrm{L}^{-1}$ at the inlet site (Fig. 2a,b). As can be judged on the basis of calculated N:P ratios (range 31163 by atoms), phytoplankton growth was usually $\mathrm{P}$ limited, although short-term nitrogen limitation at the inlet site and central site may have occurred during spring in 1996 and 1997.

Overall, patterns of abiotic variables were quite erratic, without showing clear-cut seasonal patterns or any interannual trend. As shown below, most environ- mental features did not covary with phytoplankton dynamics.

\section{Phytoplankton biomass and net primary production}

Both phytoplankton chlorophyll-a and biomass showed coefficients of variation exceeding $100 \%$. Chlorophyll-a ranged from $43.5 \pm 47.1 \mu \mathrm{g} \mathrm{L} \mathrm{L}^{-1}$ at the inlet site to $11.8 \pm 13.9 \mu \mathrm{g} \mathrm{L}^{-1}$ at the central site (Fig. $3 \mathrm{a}, \mathrm{b})$. Biomass was highest at the middle outlet and minimal at the central site $(13.56 \pm 16.26$ vs $4.18 \pm$ $5.62 \mathrm{~mm}^{3} \mathrm{~L}^{-1}$ ). Both variables were significantly different in inter-site comparisons (Friedman test, $\mathrm{p}<0.05$; Fig. 4), but within each site these variables were correlated with each other, although the explained variability was not very high (36-56\%). Biomass and chlorophyll-a showed seasonal variability.

Net PP was also very variable within and among sites (Fig. 3a,b). The lowest production occurred at central and outlet sites $\left(18 \pm 32\right.$ and $61 \pm 65 \mathrm{mg} \mathrm{C} \mathrm{m}^{-3}$ $\left.\mathrm{h}^{-1}\right)$, whereas the inlet and the central outlet showed higher values $\left(186 \pm 336\right.$ and $\left.137 \pm 225 \mathrm{mg} \mathrm{C} \mathrm{m}^{-3} \mathrm{~h}^{-1}\right)$, resulting in a significant site effect (Friedman test, $\mathrm{p}<$ 0.05; Fig. 4). The time course of net PP was strongly seasonal for the inlet and the central site, albeit values in 1996 were smoother and lower (Fig. 3a,b).

Ranges of productivity were also very wide, with maximal values at the central outlet and minimal at the central site $(5.38 \pm 8.58$ and $1.25 \pm 1.42 \mathrm{mg} \mathrm{C} \mathrm{(mg}$ Chl-a $)^{-1} h^{-1}$, all sites were significantly different from each other (Friedman test $\mathrm{p}<0.05$; Fig. 4 , s). Seasonality of productivity also took place, with highest values in summer (Fig. 3a,b).
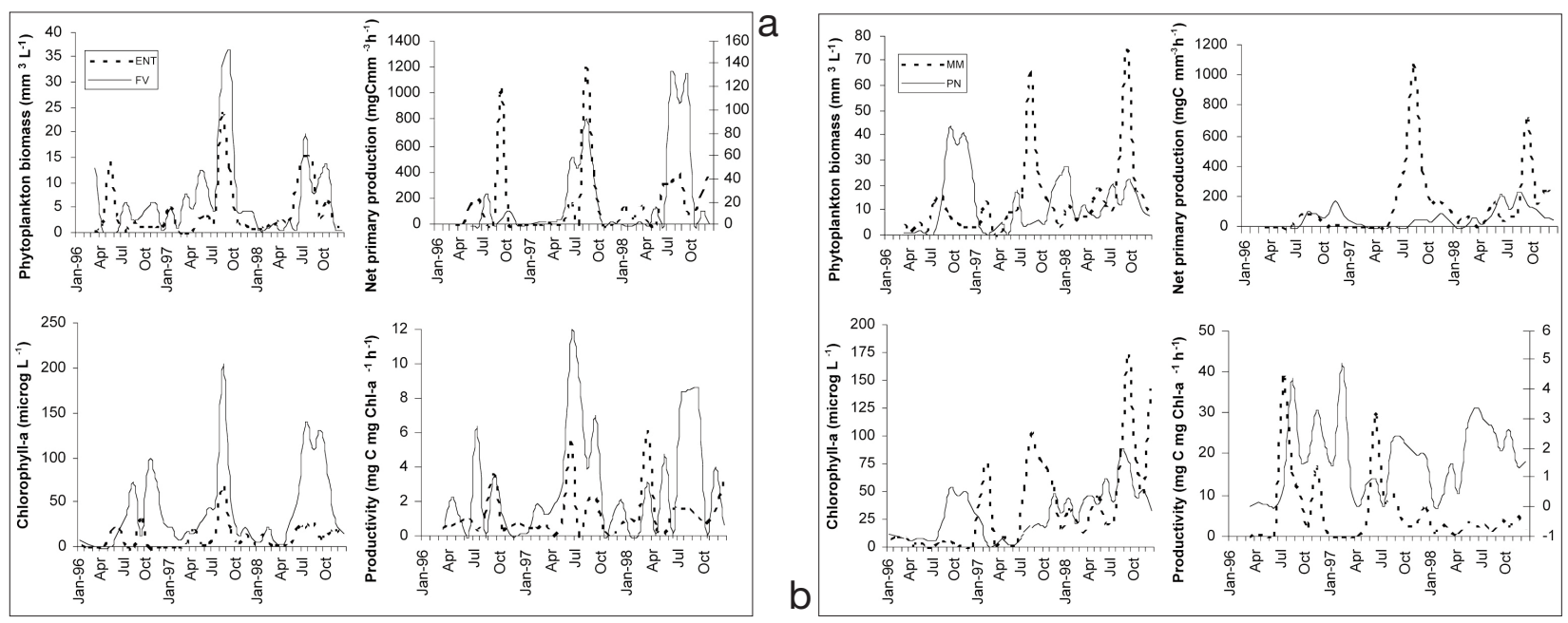

Fig. 3. Phytoplankton chlorophyll-a and biomass, net primary production and productivity time courses at four sites of Tablas de Daimiel National Park from March 1996 to December 1998. ENT, central site; FV, inlet site (Fig. 3a); MM, central outlet; PN, terminal outlet (Fig. 3b). See Fig. 1 for location. 

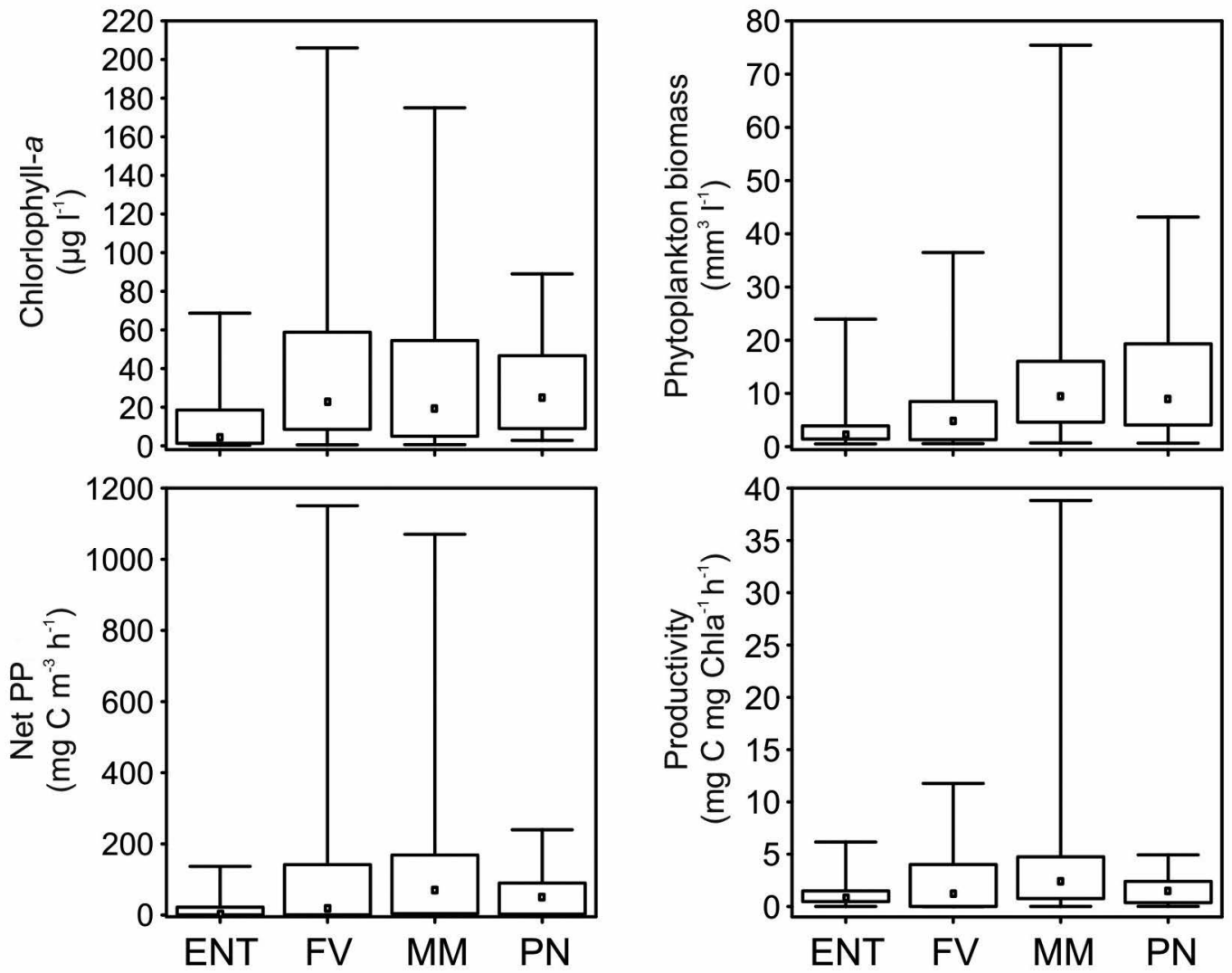

Fig. 4. Box-whisker plots of phytoplankton chlorophyll-a and biomass, net primary production and productivity at four sites of Tablas de Daimiel National Park from March 1996 to December 1998. ENT, central site; FV, inlet site; MM, central outlet; PN, terminal outlet. See Fig. 1 for location.

Annual net PP was 26-47 $\mathrm{g} \mathrm{C} \mathrm{m}^{-2} \mathrm{y}^{-1}$ at the central site and $67-580 \mathrm{~g} \mathrm{C} \mathrm{m}^{-2} \mathrm{y}^{-1}$ at the inlet. Values at the other sites showed an intermediate range (Fig. 5).

\section{Controlling factors of PP}

PAR attenuation was influenced by different variables at different sites (Table 2). At the entrance and central outlet, suspended solids partly explained attenuation variability $\left(\mathrm{R}^{2}>0.64, \mathrm{p}<0.05\right)$. At the central site, chlorophyll-a was the main variable explaining the highest fraction of attenuation $\left(\mathrm{R}^{2}=0.61, \mathrm{p}<\right.$ $0.05)$. Chlorophyll-a and coloured dissolved compounds explained attenuation at the terminal outlet site $\left(R^{2}=0.34\right.$ and 0.56 , respectively, $\left.\mathrm{p}<0.05\right)$. Chlorophyll-a explained more variability of net $\mathrm{PP}$ when both chlorophyll and DOC were related with PAR attenuation $\left(\mathrm{R}^{2}=0.71, \mathrm{p}<0.05\right)$. Regarding nutrients, only total nitrogen showed a weak inverse relationship with chlorophyll-a and net PP at the inlet site $\left(R^{2}=0.27, p<0.05\right.$; Table 2$)$. At this site, strong nutrient loading took place in winter, matching periods when net PP was lower (Figs. 2, 3). Zooplankton populations did not appear to control net PP ( $\mathrm{p}>$ 0.05 ; Table 2). Only ciliates showed a weak covariation with phytoplankton biomass at the two central sites of the wetland (Table $2 ; \mathrm{R}^{2}=0.30-0.38, \mathrm{p}<0.05$ ). Controlling factors of productivity remained elusive because none of the tested abiotic and biotic variables were significantly related to it statistically $(\mathrm{p}>0.05)$.

Net PP appeared to be related to phytoplankton abundance (measured as either chlorophyll-a or total biomass) at all wetland sites (Table $2 ; \mathrm{R}^{2}=0.38-0.77$, $\mathrm{p}<0.05)$. However, the relationship between chlorophyll-a, phytoplankton biomass and net PP was very variable among sites; the changing covariation among these variables could be related to the wide spectrum of occurring phytoplankton assemblages. At a given site, annual peak values of net PP were due to different phytoplankton assemblages, which resulted from the changing combinations of sizes and species-specific cellular chlorophyll content (see below). At the entrance and outlet sites peaks of net PP took place in summer during the co-dominance of large phytoplankters, such as Planktotbrix agardbii or Anabaena sp., with smaller algae, such as Cyclotella meneghinia- 


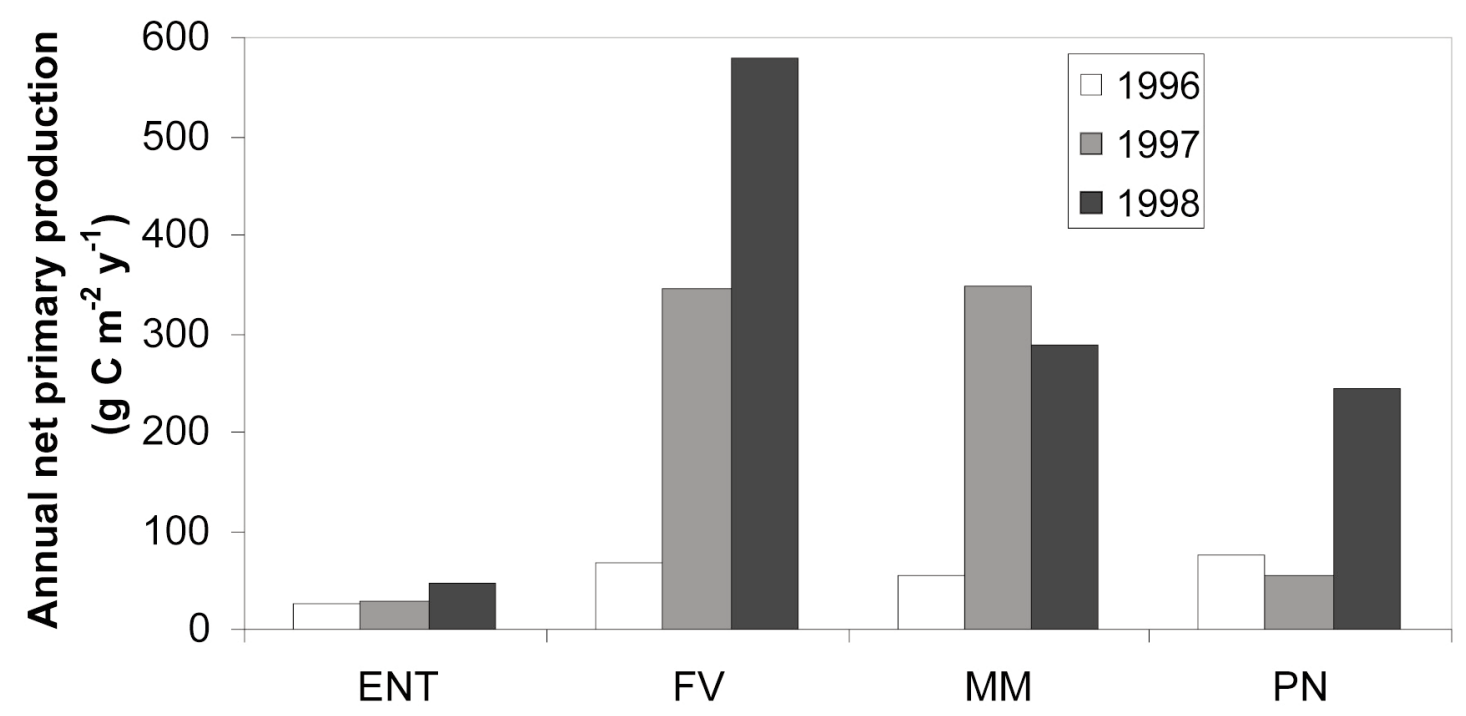

Fig. 5. Annual net phytoplankton primary production at four sites of Tablas de Daimiel National Park from March 1996 to December 1998. ENT, central site; FV, inlet site; MM, central outlet; PN, terminal outlet. See Fig. 1 for location.

na, Cryptomonas erosa or small colonies of Coelastrum spp. A rapid species substitution was observed at these sites in summer months. At the central site, however, only the larger phytoplankters contributed to production maxima; Planktothrix agardhii was dominant during the summer net PP peaks and Nitzschia acicularis in spring.

Temporal synchrony among wetland sites was low for biomass, net PP and productivity because, despite some temporal matching (Fig. 3), the highest correlations among variables explained less than $23 \%$ of overall variability. These results were found even when flooding connected all sites, thus suggesting site-specific dynamics.

\section{Macrophyte production and carbon budgets}

Results of macrophyte production are shown in Table 3. Reed and cattail fixed more carbon than cutsedge in years with higher flooding. Submerged production was increasing over time. PP ranged 3-10\% of overall helophyte production, being higher in 1998, which was the year with higher average flooding. As related with submerged macrophyte production, PP also increased over time.

When carbon budgets were estimated (Table 4), Phragmites showed the highest value of all plant populations in 1997, an intermediate year of flooding. Cladium exhibited a decreasing trend over time along with its decreasing plant cover. The Chara budget also increased over time, despite the fact that it experienced a strong population decline as a result of an acute pollution impact from the wetland catchment in 1997, but it was enhanced by the higher flooding in 1998 . The share of phytoplankton carbon increased over the study period, contributing an important fraction to the carbon budget relative to helophyte and submerged plants as average flooding increased (Table 4).

\section{Discussion}

This study demonstrates that net PP in wetlands lies within the same range of values observed in lakes. We have recorded values of primary production ranging from $18 \pm 32 \mathrm{C} \mathrm{m}^{-3} \mathrm{~h}^{-1}$ to $186 \pm 336 \mathrm{mg} \mathrm{C} \mathrm{m}^{-3} \mathrm{~h}^{-1}$ and productivity from $1.25 \pm 1.42$ to $5.38 \pm 8.58 \mathrm{mg} \mathrm{C}$ (mg Chl-a) $)^{-1} \mathrm{~h}^{-1}$. These values are common in lakes (Álvarez-Cobelas \& Rojo, 1994) and other pelagic environments (Geider \& Osborne, 1992; Reynolds, 2006). Also the few data available for wetland PP reveal that phytoplankton in Las Tablas de Daimiel fixed far more carbon than other wetlands (Table 5). Although some of the previously studied wetlands have high nutrient contents (e.g. Alberta ponds, Robarts \& al., 1995), climatic conditions such as long freezing or their temporary character could result in environmental constraints of production (Table 5). As compared with data gathered from lakes (Álvarez-Cobelas \& Rojo, 1994), the values of PP in Tablas de Daimiel National Park are somewhat high, but within the range recorded for many lakes, being also substantially lower than those observed by Talling \& al. (1973) in soda lakes of Ethiopia. Charophyte and helophyte productions in TDNP have also been within the ranges reported for other wetlands and lakes (Vymazal, 1995; 
Table 2. Results of correlation analyses showing coefficients of significant relationships $(p<0.05)$ between chlorophyll-a, total phytoplankton biomass, the biomass of different size fractions of phytoplankton and net primary production (net PP), and environmental factors at four different sites in Tablas de Daimiel National Park. Data were gathered monthly from March 1996 to December 1998. See Fig. 1 for site location. Bold numbers indicate statistical significance at $p<0.01$. Biophyto, phytoplankton biomass; DOC, dissolved organic carbon; PAR, photosynthetically available radiation. Zooplankton populations other than Ciliates did not show any statistically significant relationship with phytoplankton variables $(p>0.05)$

\begin{tabular}{|c|c|c|c|c|}
\hline ENT, CENTRAL SITE & PAR attenuation & Chlorophyll-a & Biomass & Net PP \\
\hline Chlorophyll-a & 0.78 & & 0.74 & 0.87 \\
\hline PAR attenuation & & 0.78 & & \\
\hline Net phytoplankton primary production & & 0.87 & 0.61 & \\
\hline Phytoplankton biomass & & 0.74 & & 0.61 \\
\hline Biophyto $\leqslant 50 \mu \mathrm{m}$ & & 0.74 & 0.92 & 0.63 \\
\hline Ciliate biomass & & & 0.62 & \\
\hline
\end{tabular}

\begin{tabular}{|c|c|c|c|c|}
\hline FV, INLET SITE & PAR attenuation & Chlorophyll-a & Biomass & Net PP \\
\hline Total Nitrogen & & -0.52 & & -0.51 \\
\hline Suspended solids & 0.83 & & & \\
\hline Net phytoplankton primary production & & 0.75 & 0.57 & \\
\hline Chlorophyll-a & & & 0.61 & 0.75 \\
\hline Phytoplankton biomass & & 0.61 & & 0.57 \\
\hline Biophyto $\leqslant 10 \mu \mathrm{m}$ & & & & 0.55 \\
\hline $20 \mu \mathrm{m}<$ Biophyto $\leqslant 30 \mu \mathrm{m}$ & & 0.53 & 0.95 & 0.51 \\
\hline Biophyto $>50 \mu \mathrm{m}$ & & 0.75 & 0.69 & 0.67 \\
\hline
\end{tabular}

\begin{tabular}{|c|c|c|c|c|}
\hline MM, CENTRAL OUTLET & PAR attenuation & Chlorophyll-a & Biomass & Net PP \\
\hline Chlorophyll-a & & & 0.75 & 0.68 \\
\hline DOC & 0.76 & & & \\
\hline Suspended solids & 0.81 & & & \\
\hline Net phytoplankton primary production & & 0.68 & 0.88 & \\
\hline Phytoplankton biomass & & 0.75 & & 0.88 \\
\hline Biophyto $\leqslant 10 \mu \mathrm{m}$ & & & & 0.63 \\
\hline $20 \mu \mathrm{m}<$ Biophyto $\leqslant 30 \mu \mathrm{m}$ & & 0.51 & 0.67 & \\
\hline $30 \mu \mathrm{m}<$ Biophyto $\leqslant 50 \mu \mathrm{m}$ & & & 0.58 & 0.74 \\
\hline Biophyto $>50 \mu \mathrm{m}$ & & 0.66 & 0.79 & 0.65 \\
\hline Ciliate biomass & & & 0.55 & \\
\hline
\end{tabular}

\begin{tabular}{|c|c|c|c|c|}
\hline PN, TERMINAL OUTLET & PAR attenuation & Chlorophyll-a & Biomass & Net PPP \\
\hline Chlorophyll-a & 0.58 & & 0.60 & 0.84 \\
\hline DOC & 0.75 & & & \\
\hline PAR attenuation & & 0.58 & & \\
\hline Net phytoplankton primary production & & 0.84 & & \\
\hline Phytoplankton biomass & & 0.60 & & \\
\hline $10 \mu \mathrm{m}<$ Biophyto $\leqslant 20 \mu \mathrm{m}$ & & & & 0.52 \\
\hline $20 \mu \mathrm{m}<$ Biophyto $\leqslant 30 \mu \mathrm{m}$ & & & 0.91 & \\
\hline $30 \mu \mathrm{m}<$ Biophyto $\leqslant 50 \mu \mathrm{m}$ & & & & 0.52 \\
\hline
\end{tabular}


Table 3. Average flooding ( \pm 1 standard deviation), macrophyte cover at its annual peak and annual net primary production (nPP) of phytoplankton and macrophytes in Tablas de Daimiel National Park in 1996-1998. For macrophytes only aerial production was measured. FV, ENT, MM and PN are the sites of nPP measurements, which are depicted in Fig. 1.

\begin{tabular}{|c|c|c|c|}
\hline & 1996 & 1997 & 1998 \\
\hline Average flooding area $(\mathrm{Ha})$ & $588 \pm 510$ & $1254 \pm 489$ & $1456 \pm 305$ \\
\hline Inlet (FV) nPP ( $\left.\mathrm{g} \mathrm{C} \mathrm{m}^{-2} \mathrm{y}^{-1}\right)$ & 67 & 346 & 580 \\
\hline Central site (ENT) nPP $\left(\mathrm{g} \mathrm{C}^{-2} \mathrm{y}^{-1}\right)$ & 26 & 29 & 47 \\
\hline Central outlet (MM) nPP $\left(\mathrm{g} \mathrm{C} \mathrm{m}^{-2} \mathrm{y}^{-1}\right)$ & 53 & 347 & 289 \\
\hline Outlet (PN) nPP ( $\left.\mathrm{g} \mathrm{C} \mathrm{m}^{-2} \mathrm{y}^{-1}\right)$ & 74 & 55 & 243 \\
\hline Average $\mathrm{nPP}\left(\mathrm{g} C \mathrm{~m}^{-2} \mathrm{y}^{-1}\right)$ & 55 & 194 & 290 \\
\hline Chara cover $(\mathrm{Ha})$ & 600 & 200 & 250 \\
\hline Phragmites cover $(\mathrm{Ha})$ & 736 & 669 & 709 \\
\hline Cladium cover $(\mathrm{Ha})$ & 325 & 307 & 300 \\
\hline Typha cover $(\mathrm{Ha})$ & 0 & 120 & 110 \\
\hline Chara production $\left(\mathrm{g} \mathrm{C} \mathrm{m}^{-2} \mathrm{y}^{-1}\right)$ & $221 \pm 48$ & $776 \pm 125$ & $800 \pm 158$ \\
\hline Cladium production $\left(\mathrm{g} \mathrm{C}^{-2} \mathrm{y}^{-1}\right)$ & $1495 \pm 903$ & $766 \pm 544$ & $527 \pm 323$ \\
\hline Phragmites production $\left(\mathrm{g} \mathrm{C} \mathrm{m}^{-2} \mathrm{y}^{-1}\right)$ & $633 \pm 242$ & $2236 \pm 745$ & $1197 \pm 576$ \\
\hline 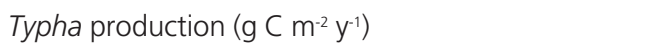 & 0 & $2662 \pm 889$ & $1258 \pm 620$ \\
\hline Averaged total production of helophytes $\left(\mathrm{g} \mathrm{C} \mathrm{m}^{-2} \mathrm{y}^{-1}\right)$ & 2128 & 5664 & 2982 \\
\hline$\%$ nPP of average helophyte production & 3 & 3 & 10 \\
\hline$\%$ nPP of average charophyte production & 25 & 25 & 36 \\
\hline
\end{tabular}

Cronk \& Fennessy, 2001; Kufel \& Kufel, 2002).

When comparing macrophyte production and PP in TDNP our results reveal that net PP can comprise $25-36 \%$ of charophyte and $3-10 \%$ of total helophyte carbon production in this wetland (Table 3). These fractions increase when carbon budgets for the entire wetland are considered (Table 3), because the phytoplankton budget may attain up to $37 \%$ of helophyte carbon budget in years of high flooding. Thus, in the case of the studied wetland, phytoplankton cannot be considered a negligible fraction when addressing carbon metabolism in high flooding years. These results suggest that the importance of phytoplankton to overall primary production in wetlands may have been underestimated in the past, particularly in wetlands where flooding does not show strong fluctuations, such as in cold temperate areas of the World. In many wetlands such a contribution could be high and should be taken into account for computing accurate carbon budgets.

Table 4. Carbon budgets (tons $C^{-1}$ ) in Las Tablas de Daimiel National Park for the main plant communities in 1996-1998. It was assumed that phytoplankton is evenly distributed across the flooded area.

\begin{tabular}{|c|c|c|c|}
\hline & 1996 & 1997 & 1998 \\
\hline Phytoplankton & 367 & 2433 & 4222 \\
\hline Chara & 1326 & 1552 & 2000 \\
\hline Cladium & 4859 & 2351 & 1581 \\
\hline Phragmites & 4659 & 14949 & 8487 \\
\hline Typha & 0 & 3194 & 1384 \\
\hline Total helophytes & 9518 & 20494 & 11452 \\
\hline$\%$ phytoplankton budget of helophyte budget & 4 & 12 & 37 \\
\hline$\%$ phytoplankton budget of charophyte budget & 27 & 157 & 211 \\
\hline
\end{tabular}




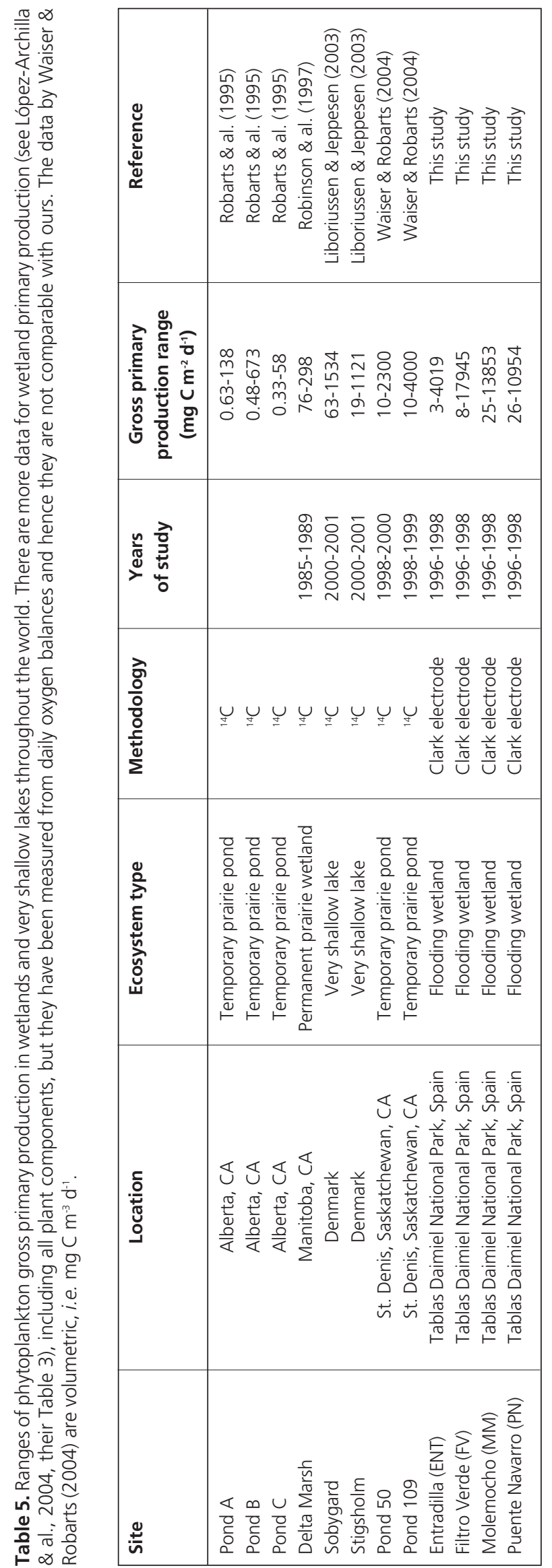

The seasonality of PP is driven by seasonal variability of irradiance patterns. However, our results (Fig. 3) do not show much temporal coherence among different wetland sites, despite hydrological connectivity for one third of the study period. A previous study on the chemical environment of this wetland for the same years has demonstrated that local scale processes have been more important for regulating wetland processes than connectivity between sites (Álvarez-Cobelas \& al., 2007; Angeler \& al., 2010). Moreover, structural and dynamic features of phytoplankton assemblages lacked a common pattern among sites in this wetland and displayed stochastic trajectories (Rojo \& al., 2000). This typically occurs in eutrophic to hypertrophic wetlands, where sediment, macrophytes, hydrological perturbations, nutrient supply variability and site-specific underwater light conditions jointly affect phytoplankton, thus masking the otherwise well-known bottom-up or top-down controls on phytoplankton (Wetzel, 1990; Hairston, 1996, ChowFraser \& al., 1998; Angeler \& al., 2000; OrtegaMayagoitia \& al., 2002; Schallenberg \& Burns, 2004).

The wetland landscape heterogeneity depends on water inflows which affect inundation and in turn plankton dynamics; the strong interannual and among-site variability of inflows precludes the occurrence of a seasonal plankton pattern similar to what is expected in lakes (Angeler \& al., 2000). The TDNP wetland is hypertrophic as a result of high loading of nutrients since 1980; during the studied period, nutrients displayed distinct seasonality (Fig. 2), the variation in both total nitrogen and phosphorus concentration was related to dry or wet years, and an important spatial heterogeneity in nutrient content occurred throughout the study (Álvarez-Cobelas \& al., 2007). Therefore, no relationships were found between nutrient concentrations and phytoplankton biomass (Rojo \& al., 2000; Sánchez-Carrillo \& Álvarez-Cobelas, 2001). Matching this, nutrients did not appear to control net PP (Table 2). Nutrients have often been shown to poorly explain PP in wetlands (Robarts \& al., 1995). In these systems, PP seems to be affected by interlinked abiotic and biotic processes, such as sediment metabolism and its interaction with plankton dynamics (Ortega-Mayagoitia \& al., 2002, 2003; Waiser \& Robarts, 2004).

Zooplankton structure and dynamics were subjected to strong hydrologic fluctuations and mostly reflected a composition indicative of high fish predation (Angeler \& al., 2002). Ciliates were the most important component of zooplankton in terms of biomass. The presence of omnivorous copepods, rather than large effective filter feeders, (Daphnids) did not result 
in strong top-down control (Ortega-Mayagoitia \& al., $2000,2002)$. The lack of zooplankton control on primary production variability may then be explained by the dominance of large-size classes of phytoplankton species that may well withstand predation from smallsized zooplankters. The lack of relationship with nutrients also suggested that PP was not nutrient-limited and that therefore nutrient recycling by zooplankton had a marginal effect on PP.

A further factor affecting plankton processes in shallow environments is the sediment (Schallenberg \& Burns, 2004; Levine \& al., 2005). The influence of sediment interaction with planktonic processes in the water column has also experimentally been demonstrated in this wetland (Ortega-Mayagoitia \& al., 2003). Table 2 even suggests that the quality of the underwater light climate at different sites partly depended on sediment resuspension processes; for instance, resuspended matter increases attenuation at the wetland inlet site. At the central site chlorophyll-a, and thus algal turbidity, becomes the most important factor for light extinction because charophytes limit sediment resuspension. In other areas of the wetland, decomposition of higher plants and resuspension of peat controls the underwater light field in the very shallow waters. Thus, this wetland comprises several irradiance-distribution features that have been observed independently in humic (Eloranta, 1999), clearwater (Talling, 1971) and turbid lakes (Grobbelaar, 1985).

Phytoplankton community descriptors were not related with productivity, which partly arose from the fact that differently-sized organisms with contrasting physiological characteristics caused peaks of net PP during different periods (Ortega-Mayagoitia \& al., 2002). For example, while the biovolume-scaled chlorophyll-a content of Cyclotella meneghiniana is $1.5 \mu \mathrm{g} \mathrm{Chl}-\mathrm{a} \mathrm{mm}^{-3}$, it is three times higher in Plank-

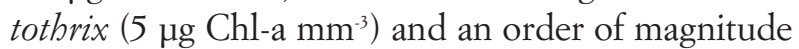
higher in small green algae (Olrik, 1994).

Covariability of net PP, chlorophyll-a, phytoplankton biomass and phytoplankton size distribution was site-dependent, possibly arising from differing regimes of irradiance quantity and quality. It is a well known fact that the quality and availability of PAR are controlling factors of phytoplankton composition in shallow environments without limiting nutrients (Reynolds, 2006). In this wetland an overlap of phytoplankton functional groups (C, S1 and Y, sensu Reynolds \& al., 2002) took place from late spring to late summer in highly turbid sites (Rojo \& al., 2000), thus comprising a mixed assemblage of $\mathrm{r}-\mathrm{K}$ strategists. Therefore, maximal net $\mathrm{PP}$ was recorded at those sites when large- or small-sized, low light-tolerant phyto- plankters occurred. These species might have different chlorophyll-a content and pigment composition, an example of which was Planktothrix agardhii, a species with high production rates during PAR-deficient conditions (Reynolds, 2006), despite its low chlorophyll-content.

Simultaneously, at the central site where a Charophyte meadow stabilizes sediments and reduces sediment resuspension, maximal net PP was due to two alternating phytoplankton assemblages (D and S1 functional groups sensu Reynolds \& al., 2002), namely, an epipelic light-stressed meroplankton (dominated by Nitzschia acicularis; Roeder, 1977), which has a low chlorophyll-a content and is a relatively productive population (Schallenberg \& Burns, 2004), and a group dominated by Planktothrix.

To summarize, this wetland shows a seasonal pattern of net PP which is highly heterogeneous spatially. This heterogeneity is due to the activity of distinct phytoplankton assemblages as a function of site-specific environmental controlling factors. Despite this heterogeneity, planktonic primary production can contribute substantially to the carbon budget of wetlands, suggesting that the calculation of carbon balances in wetlands is inaccurate if phytoplankton is ignored. Finally, our study demonstrates that hydrology is responsible for the contribution of phytoplankton to the carbon budget of wetlands, i.e. the higher the flooding the higher the quantity of carbon phytoplankton.

\section{Acknowledgements}

This is a contribution of Projects 81/05 and 01/09 of the Spanish Ministry of Environment. Alfonso Díaz-Cambronero of the National Park staff supplied us meteorological data. Manuel Carrasco-Redondo, the National Park Director when field sampling of this study was carried out, and Carlos Ruiz de la Hermosa, who was appointed as Director after 2005, provided logistic and financial support for field campaigns and calculations. We also thank Elizabeth Ortega-Mayagoitia and Palmira Riolobos for plankton counting and nutrient analyses, respectively. An anonymous referee suggested many useful criticisms. Antonio Flores-Moya is also acknowledged for his insightful work as associate editor.

\section{References}

Álvarez-Cobelas, M. \& Jacobsen, B.A. 1992. Hypertrophic phytoplankton: an overview. Freshwater Forum 2: 184-199.

Álvarez-Cobelas, M. \& Rojo, C. 1994. Spatial, seasonal and long term variability of phytoplankton photosynthesis in lakes. Journal of Plankton Research 16: 1691-1716.

Álvarez-Cobelas, M. \& Cirujano, S. (eds.) 1996. Las Tablas de Daimiel: ecología acuática y sociedad. Ministerio de Medio Ambiente. Madrid.

Álvarez-Cobelas, M., Cirujano, S. \& Sánchez-Carrillo, S. 2001. Hydrological and botanical man-made changes in the Spanish wetland of Las Tablas de Daimiel. Biological Conservation 97: 89-97.

Álvarez-Cobelas, M. \& Cirujano, S. 2007. Multilevel responses of 
emergent vegetation to environmental factors in a semiarid floodplain. Aquatic Botany 87: 49-60.

Álvarez-Cobelas, M., Sánchez-Carrillo, S. \& Cirujano, S. 2007. Strong site effects dictate nutrient patterns in a Mediterranean floodplain. Wetlands 27: 326-336.

Álvarez-Cobelas, M., Sánchez-Carrillo, S., Cirujano, S. \& Angeler, D.G. 2010. A story of the wetland water quality deterioration: salinization, pollution, eutrophication and siltation. In: SánchezCarrillo, S. \& Angeler, D.G. (eds.), Ecology of threatened semiarid Wetlands: Long-term Research in Las Tablas de Daimiel: 109-133. Springer Verlag. Berlin.

Angeler, D.G., Álvarez-Cobelas, M., Rojo, C. \& Sánchez-Carrillo, S. 2000. The significance of water inputs on plankton biomass and trophic relationships in a semiarid freshwater wetland. Journal of Plankton Research 22: 2075-2094.

Angeler, D.G., Álvarez-Cobelas, M., Sánchez-Carrillo, S. \& Rodrigo, M.A. 2002. Assessment of exotic fish impacts on water quality and zooplankton in a degraded semi-arid floodplain wetland. Aquatic Sciences 64: 76-86.

Angeler, D.G., Álvarez-Cobelas, M., Rojo, C. \& Sánchez-Carrillo, S. 2010. Phytoplankton community similarity in a semiarid floodplain under contrasting hydrological connectivity regimes. Ecological Research: in press DOI: 10.1007/s11284-009-0681-7.

APHA, 1998. Standard Methods for the Examination of Water and Wastewater. 20th edition. Washington D.C.

Barber, R.T. \& Hilting, A.K. 2002. History of the study of plankton productivity. In: Williams, P.J. Le B, Thomas, D.N. \& Reynolds, C.S. (eds.), Phytoplankton Productivity: 16-43. Blackwell. Oxford.

Bender, M., Grande, K., Johnson, K., Marra, J., Williams, P.J. LeB, Sieburth, J., Pilson, M., Langdon, C., Hitchcock, G., Orchardo, J., Hunt, C., Donaghay, P. \& Heinemann, K. 1987. A comparison of four methods for determining planktonic primary production. Limnology and Oceanography 32: 1085-1098.

Brylinsky, M. 1980. Estimating the productivity of lakes and reservoirs. In: Le Cren, E.D. \& Lowe-McConnell, R.H. (eds.), The Functioning of Freshwater Ecosystems: 411-454. Cambridge University Press. Cambridge.

Carignan, R., Planas, D. \& Vis, C. 2000. Production and respiration in oligotrophic Shield lakes. Limnology and Oceanography 45: 189-199.

Chow-Fraser, P., Lougheed, V., Thiec, V.L., Crosbie, B., Simser, L. \& Lord, J. 1998. Long-term response of the biotic community to fluctuating water levels and changes in water quality in Cootes Paradise Marsh, a degradated coastal wetland of Lake Ontario. Wetlands Ecology and Management 6: 19-42.

Cronk, J.K. \& Fennessy, M.S. 2001. Wetland Plants. Biology and Ecology. Lewis Publishers. Boca Ratón.

Cuthbert, I.D. \& del Giorgio, P. 1992. Toward a standard method of measuring color in freshwater. Limnology and Oceanography 37: 1319-1326.

Eloranta, P. 1999. Humus and water physics. In: Keskitalo, J. \& Eloranta, P. (eds.), Limnology of Humic Waters: 59-74. Backhuys. Leiden.

ESRI, 1996. Arcview-Gis 3.0. Environmental Systems Research Institute. Redlands.

Geider, R.J. \& Osborne, B.A. 1992. Algal Photosynthesis. Chapman and Hall. New York.

George, D.G., Talling, J.F. \& Rigg, E. 2000. Factors influencing the temporal coherence of five lakes in the English Lake District. Freshwater Biology 43: 449-461.

Gessner, M.O., Schieferstein, B., Müller, U., Barkmann, S. \& Lenfers, U.A. 1996. A partial budget of primary production carbon flows in the littoral zone of a hardwater lake. Aquatic Botany 55: 93-105.
Grobbelaar, J. 1985. Phytoplankton productivity in turbid waters. Journal of Plankton Research 7: 653-663.

Hairston, N.G. 1996. Zooplankton egg banks as biotic reservoirs in changing environments. Limnology and Oceanography 41: 1087-1092.

Harris, G.P. 1973. Diel and annual cycles of net plankton photosynthesis in Lake Ontario. Journal of the Fisheries Research Board of Canada 30: 1779-1787.

Harris, G.P. 1978. Photosynthesis, productivity and growth: the physiological ecology of phytoplankton. Archiv für Hydrobiologie, Ergebnisse der Limnologie 10: 1-171.

Harris, G.P. 1986. Phytoplankton Ecology. Chapman and Hall. London.

Harris, G.P. \& Lott, J.N.A. 1973. Light intensity and photosynthetic rates in phytoplankton. Journal of the Fisheries Research Board of Canada 30: 1771-1778.

Harris, G.P. \& Piccinin, B.B. 1977. Photosynthesis by natural phytoplankton populations. Archiv für Hydrobiologie 80: 405-457.

Kirk, J.T.O. 1994. Light and Photosynthesis in Aquatic Ecosystems. $2^{\text {nd }}$ edition. Cambridge University Press. Cambridge.

Kufel, L. \& Kufel, I. 2002. Chara beds acting as nutrient sink in shallow lakes - a review. Aquatic Botany 72: 249-260.

Leibowitz, S. \& Vining, K.V. 2003. Temporal connectivity in a prairie pothole complex. Wetlands 23: 13-25.

Levine, S.N., Zehrer, R. \& Burns, C.W. 2005. Impact of resuspended sediment on zooplankton feeding in Lake Waihola, New Zealand. Freshwater Biology 50: 1515-1536.

Liboriussen, L. \& Jeppesen, E. 2003. Temporal dynamics in epipelic, pelagic and epiphytic algal production in a clear and a turbid shallow lake. Freshwater Biology 48: 418-431.

Lomnicki, A., Bandola, E. \& Jankowska, K. 1968. Modification of the Wiegert-Evans method for estimation of net primary production. Ecology 49: 147-149.

López-Archilla, A.I., Mollá, S., Coleto, M.C., Guerrero, M.C. \& Montes, C. 2004. Ecosystem metabolism in a Mediterranean shallow lake (Laguna de Santa Olalla, Doñana National Park, SW Spain). Wetlands 24: 848-858.

Lund, J.W.G., Kipling, C. \& Le Cren, E.D. 1957. The inverted microscope method of estimating algal numbers, and the statistical basis of estimations by counting. Hydrobiologia 11: 143-170.

Manning, W.M. \& Juday, C.E. 1941. The chlorophyll content and productivity of some lakes in Northeastern Wisconsin. Transactions of the Wisconsin Academy of Sciences, Arts and Letters 33: 363-393.

Marker, A.F.H., Nusch, E.A., Rai, H. \& Riemann, B. 1980. The measurement of photosynthetic pigments in freshwater and standardization of methods: conclusions and recommendations. Archiv für Hydrobiologie, Ergebnisse der Limnologie 14: 91-106.

Marra, J. 2002. Approaches to the measurement of plankton production. In: Williams, P. Le B, Thomas, D.N. \& Reynolds, C.S. (eds.), Phytoplankton Productivity: 78-108. Blackwell. Oxford.

McCauley, E. 1984. The estimation of the abundance and biomass of zooplankton in samples. In: Downing, J.A. \& Rigler, F.H. (eds.), A Manual on the Assessment of Secondary Production in Freshwaters: 228-265. Blackwell. Oxford.

Micheletti, S., Schanz, F. \& Walsby, A.E. 1998. The daily integral of photosynthesis by Planktothrix rubescens during summer stratification and autumnal mixing in Lake Zürich. New Phytologist 139: 233-246.

Mitsch, W.J. \& Gosselink, J.G. 2001. Wetlands. Third edition. John Wiley and Sons. New York.

Olrik, K. 1994. Phytoplankton Ecology. Miljøprojekt 251. Danish Environmental Protection Agency. Copenhagen.

Ortega-Mayagoitia, E., Rojo, C. \& Armengol, J. 2000. Structure and dynamics of zooplankton in a semi-arid wetland, the National Park Las Tablas de Daimiel (Spain). Wetlands 20: 629-638. 
Ortega-Mayagoitia, E., Rojo, C. \& Rodrigo, M.A. 2002. Factors masking the trophic cascade in shallow eutrophic wetlands evidence from a microcosm study. Archiv für Hydrobiologie 155: 43-63.

Ortega-Mayagoitia, E., Rojo, C. \& Rodrigo, M.A. 2003. Controlling factors of phytoplankton taxonomic structure in wetlands: an experimental approach. Hydrobiologia 502: 177-186.

Rasmussen, J.B., Godbout, L. \& Schallenberg, M. 1989. The humic content of lake water and its relationship to watershed and lake morphometry. Limnology and Oceanography 34: 13361343.

Reynolds, C.S. 2006. Ecology of Phytoplankton. Cambridge University Press. Cambridge.

Reynolds, C.S., Huszar, V.L., Kruk, C., Naselli-Flores, L. \& Melo, S. 2002. Towards a functional classification of the freshwater phytoplankton. Journal of Plankton Research 24: 417-428.

Robarts, R.D., Donald, D.B. \& Arts, M.T. 1995. Phytoplankton primary production of three temporary Northern prairie wetlands. Canadian Journal of Fisheries and Aquatic Sciences 52: 897-902.

Robinson, G.G.C., Gurney, S.E. \& Goldsborough, L.G. 1997. The primary productivity of benthic and planktonic algae in a prairie wetland under controlled water-level regimes. Wetlands 17: $182-194$

Rodhe, W. 1958. Primärproduktion und Seetypen. Verhandlungen der Internationalen Vereinigung für Limnologie 13: 121141.

Roeder, D. 1977. Relationship between phytoplankton and periphyton communities in a central Iowa stream. Hydrobiologia 56: $145-151$.

Rojo, C., Ortega-Mayagoitia, E., Rodrigo, M.A. \& Álvarez-Cobelas, M. 2000. Phytoplankton structure and dynamics in the semiarid wetland National Park Las Tablas de Daimiel (Spain). Archiv für Hydrobiologie 148: 397-419.

Rott, E. 1981. Some results from phytoplankton counting intercalibrations. Schweizerische Zeitschrift für Hydrologie 43: 34-62.

Sánchez-Carrillo, S. \& Álvarez-Cobelas, M. 2001. Nutrient dynamics and eutrophication patterns in a semiarid wetland: the effects of fluctuating hydrology. Water, Air and Soil Pollution 131: 97-118.

Sánchez-Carrillo, S. \& Angeler, D.G. (eds.) 2010. Ecology of threatened semi-arid Wetlands: Long-term Research in Las Tablas de Daimiel. Springer Verlag. Berlin.

Sánchez-Carrillo, S., Álvarez-Cobelas, M., Cirujano, S., Riolobos, P., Moreno, M. \& Rojo, C. 2000. Rainfall-driven changes in the biomass of a semiarid wetland. Verbandlungen der Internationalen Vereinigung für Limnologie 27: 1690-1694.
Schallenberg, M. \& Burns, C.W. 2004. Effects of sediment resuspension on phytoplankton production: teasing apart the influences of light, nutrients and algal entrainment. Freshwater Biology 49: $143-159$

Talling, J.F. 1957. Photosynthetic characteristics of some fresh water plankton diatoms in relation to under water radiation. New Phytologist 56: 29-49.

Talling, J.F. 1971. The underwater light climate as a controlling factor in the production ecology of freshwater phytoplankton. Mitteilungen der Internationalen Vereinigung für Limnologie 19: $214-243$.

Talling, J.F., Wood, R.B., Prosser, M.V. \& Baxter, R.M. 1973. The upper limit of photosynthetic productivity by phytoplankton: evidence from Ethiopian soda lakes. Freshwater Biology 3: 53-76.

Vymazal, J. 1995. Algae and Element Cycling in Wetlands. Lewis Publishers. Boca Ratón.

Waiser, M. \& Robarts, R.D. 2004. Net heterotrophy in productive prairie wetlands with high DOC concentrations. Aquatic Microbial Ecology 34: 279-290.

Walsby, A.E. 1997. Numerical integration of phytoplankton photosynthesis through time and depth in a water column. New Phytologist 136: 189-209.

Weisse, T. 1988. Dynamics of autotrophic picoplankton in Lake Constance. Journal of Plankton Research 10: 1179-1188.

Westlake, D.F., Adams, M.S., Bindloss, M.E., Ganf, G.G., Gerloff, G.C., Hammer, U.T., Javornický, P., Koonce, J.F., Marker, A.F.H., McCracken, M.D., Moss, B., Nauwerck, A., Pyrina, I.L., Steel, J.A.P., Tilzer, M.M. \& Walters, C.J. 1980. Primary production. In: Le Cren, E.D. \& Lowe-McConnell, R.H. (eds.), The Functioning of Freshwater Ecosystems: 141246. Cambridge University Press. Cambridge.

Wetzel, R.G. 1964. A comparative study of the primary productivity of higher aquatic plants, periphyton, and phytoplankton in a large, shallow lake. Internationale Revue der gesamten Hydrobiologie 49: 1-61.

Wetzel, R.G. 1990. Land-water interfaces: Metabolic and limnological regulators. Verhandlungen der Internationalen Vereinigung für Limnologie 23: 1041-1048.

Wetzel, R.G. 2001. Limnology. Third edition. Academic Press. San Diego.

Williams, P. LeB, Raine, R.C.T. \& Bryan, J.R. 1979. Agreement between the ${ }^{14} \mathrm{C}$ methods of measuring phytoplankton production: reassessment of the photosynthetic quotient. Oceanologica Acta 2: 411-416.

Associate Editor: A. Flores Received: 4-X-2010

Accepted: 24-VI-2011 